\title{
Front Matter: Volume 10686
}

, "Front Matter: Volume 10686," Proc. SPIE 10686, Silicon Photonics: From Fundamental Research to Manufacturing, 1068601 (20 August 2018); doi: $10.1117 / 12.2502797$

SPIE. Event: SPIE Photonics Europe, 2018, Strasbourg, France 


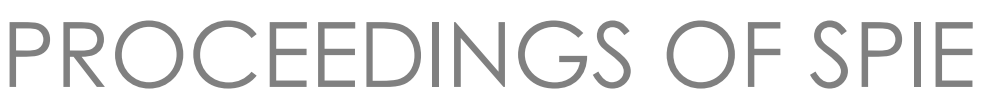

\title{
Silicon Photonics: From Fundamental Research to Manufacturing
}

\author{
Roel G. Baets \\ Peter O'Brien \\ Laurent Vivien \\ Editors
}

23-26 April 2018

Strasbourg, France

Sponsored by

SPIE

Cosponsored by

Strasbourg the Europtimist (France)

CNRS (France)

Investissements d'Avenvir (France)

iCube (France)

Université de Strasbourg (France)

Cooperating Organisations

Photonics 21 (Germany)

EOS-European Optical Society (Germany)

Photonics Public Private Partnership (Belgium)

Comité National d'Optique et de Photonique (France)

Published by

SPIE 
The papers in this volume were part of the technical conference cited on the cover and title page. Papers were selected and subject to review by the editors and conference program committee. Some conference presentations may not be available for publication. Additional papers and presentation recordings may be available online in the SPIE Digital Library at SPIEDigitalLibrary.org.

The papers reflect the work and thoughts of the authors and are published herein as submitted. The publisher is not responsible for the validity of the information or for any outcomes resulting from reliance thereon.

Please use the following format to cite material from these proceedings:

Author(s), "Title of Paper," in Silicon Photonics: From Fundamental Research to Manufacturing, edited by Roel G. Baets, Peter O'Brien, Laurent Vivien, Proceedings of SPIE Vol. 10686 (SPIE, Bellingham, WA, 2018) Seven-digit Article CID Number.

ISSN: 0277-786X

ISSN: 1996-756X (electronic)

ISBN: 9781510618985

ISBN: 9781510618992 (electronic)

Published by

SPIE

P.O. Box 10, Bellingham, Washington 98227-0010 USA

Telephone +1 3606763290 (Pacific Time) · Fax +1 3606471445

SPIE.org

Copyright (C) 2018, Society of Photo-Optical Instrumentation Engineers.

Copying of material in this book for internal or personal use, or for the internal or personal use of specific clients, beyond the fair use provisions granted by the U.S. Copyright Law is authorized by SPIE subject to payment of copying fees. The Transactional Reporting Service base fee for this volume is $\$ 18.00$ per article (or portion thereof), which should be paid directly to the Copyright Clearance Center (CCC), 222 Rosewood Drive, Danvers, MA 01923. Payment may also be made electronically through CCC Online at copyright.com. Other copying for republication, resale, advertising or promotion, or any form of systematic or multiple reproduction of any material in this book is prohibited except with permission in writing from the publisher. The CCC fee code is 0277$786 \mathrm{X} / 18 / \$ 18.00$.

Printed in the United States of America.

Publication of record for individual papers is online in the SPIE Digital Library.

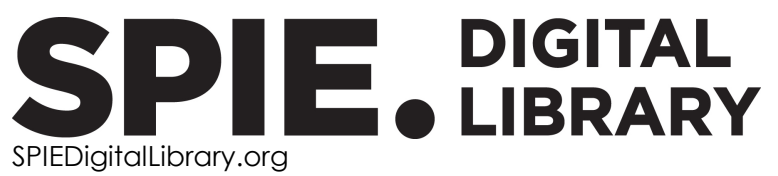

Paper Numbering: Proceedings of SPIE follow an e-First publication model. A unique citation identifier (CID) number is assigned to each article at the time of publication. Utilization of CIDs allows articles to be fully citable as soon as they are published online, and connects the same identifier to all online and print versions of the publication. SPIE uses a seven-digit CID article numbering system structured as follows:

- The first five digits correspond to the SPIE volume number.

- The last two digits indicate publication order within the volume using a Base 36 numbering system employing both numerals and letters. These two-number sets start with $00,01,02,03,04$, 05, 06, 07, 08, 09, 0A, OB ... 0Z, followed by 10-1Z, 20-2Z, etc. The CID Number appears on each page of the manuscript. 


\title{
Contents
}

\author{
$\checkmark \quad$ Authors \\ vii Conference Committee
}

LASERS AND AMPLIFIERS

10686 OC SiGeSn material for integrated optical devices (Invited Paper) [10686-11]

10686 OF Integrated rare-Earth doped mode-locked lasers on a CMOS platform (Invited Paper) [10686-14]

III-V ON SI PHOTONIC DEVICES AND CIRCUITS

10686 0J Repeaterless data transmission at $1310 \mathrm{~nm}$ using silicon photonic integrated circuit [10686-18]

10686 OK Ultrahigh efficiency III-V on Si MOS capacitor optical modulator (Invited Paper) [10686-19]

$10686 \mathrm{OL}$ Toward a hybrid integration of a 4-wavelength InGaAsP laser array on the slotted silicon waveguide [10686-20]

MID-IR PHOTONICS

10686 OM Ge/SiGe photonic devices for the long mid-infrared [10686-21]

$1068600 \quad 7.5$ - $\mu \mathrm{m}$ wavelength fiber-chip grating couplers for Ge-rich SiGe photonics integrated circuits (Best Student Paper Award) [10686-23]

10686 OP Ge-rich SiGe waveguides for supercontinuum generation in the mid-IR [10686-24]

MODE DIVERSITY AND LIGHT COUPLING

10686 OR Mode converters based on periodically perturbed waveguides for mode division multiplexing [10686-26]

10686 OS Vertically bent silicon waveguide for high-efficiency optical fiber coupling (Invited Paper) [10686-27] 
10686 OT Low-loss grating-coupled optical interfaces for large-volume fabrication with deep-ultraviolet optical lithography [10686-28]

\section{WAVELENGTH DIVERSITY DEVICES AND SYSTEMS}

10686 OV Low crosstalk silicon arrayed waveguide gratings for on-chip optical multiplexing [10686-30]

10686 OW Integrated SiN on SOI dual photonic devices for advanced datacom solutions [10686-31]

10686 OY Silicon photonic micro-ring resonator dedicated to an optoelectronic oscillator loop [10686-33]

\section{POSTERS-MONDAY}

1068617 Sub-nanometer narrow bandwidth gratings using deeply etched SOI rib waveguides [10686-34]

$1068618 \quad$ Novel ultra low power optical memory using liquid crystal [10686-43]

1068619 Plasmonic dipole nanoantennas on a SiO $2 /$ Si substrate and their characterization undefined [10686-44]

10686 IA Silicon-on-insulator-based slab to slot waveguide mode coupler [10686-45]

10686 1C Visible light emitting waveguide on Si chip [10686-47] 


\section{Authors}

Numbers in the index correspond to the last two digits of the seven-digit citation identifier (CID) article numbering system used in Proceedings of SPIE. The first five digits reflect the volume number. Base 36 numbering is employed for the last two digits and indicates the order of articles within the volume. Numbers start with 00, 01, 02, 03, 04, 05, 06, 07, 08, 09, OA, OB...0Z, followed by 10-1Z, 20-2Z, etc.

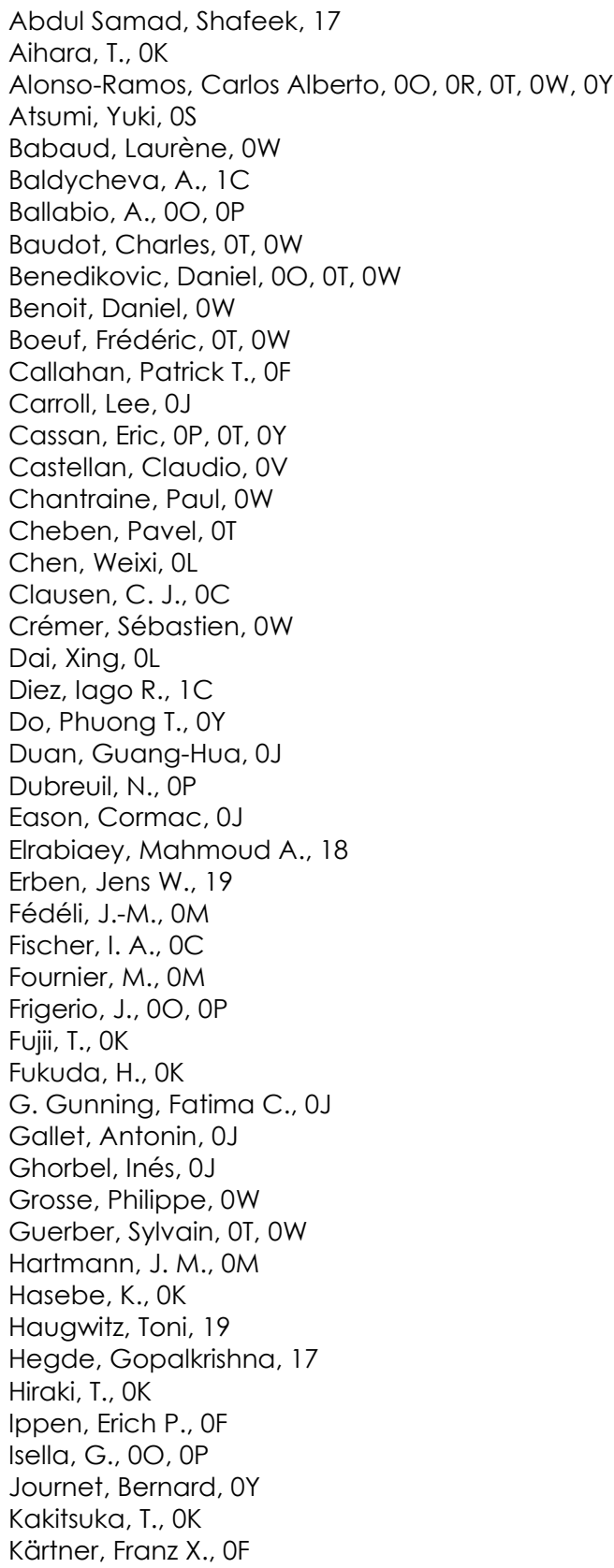

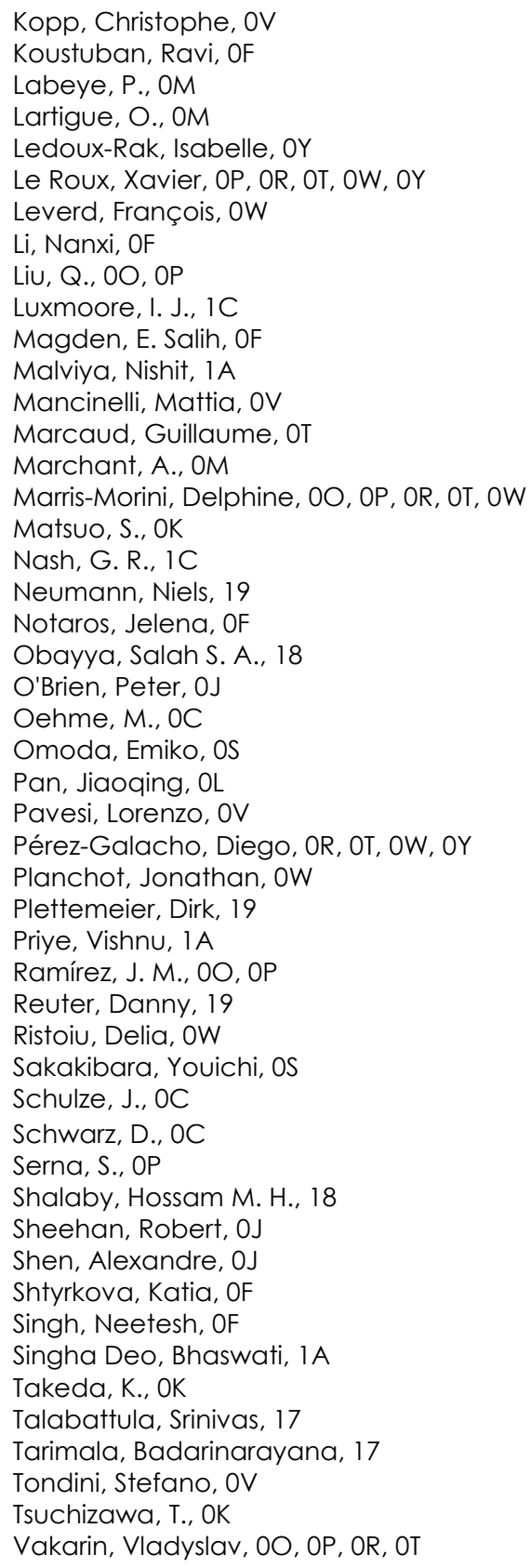


Vermeulen, Diedrik, OF

Vivien, Laurent, OO, OP, OR, OT, OW, OY

Vulliet, Nathalie, OW

Wang, Pengfei, OL

Watts, Michael R., OF

Xin, Ming, OF

Yoshida, Tomoya, OS

Youssef, El-Sayed A., 18

Yu, Hongyan, OL

Proc. of SPIE Vol. $106861068601-6$

Downloaded From: https://www.spiedigitallibrary.org/conference-proceedings-of-spie on 26 Apr 2023 Terms of Use: https://www.spiedigitallibrary.org/terms-of-use 


\section{Conference Committee}

Symposium Chairs

Francis Berghmans, Vrije Universiteit Brussel (Belgium)

Thierry Georges, Oxxius SA (France)

Harald Giessen, Universität Stuttgart (Germany)

Paul Montgomery, Université de Strasbourg (France)

Conference Chairs

Roel G. Baets, Photonics Research Group (Belgium)

Peter O'Brien, Tyndall National Institute (Ireland)

Laurent Vivien, Centre de Nanosciences et de Nanotechnologies

(France)

Conference Programme Committee

Frédéric Boeuf, STMicroelectronics (France)

Jean-Marc Fédéli, CEA-LETI (France)

José Capmany Francoy, Universitat Politécnica de València (Spain)

Frederic Y. Gardes, University of Southampton (United Kingdom)

Martijn J. R. Heck, Aarhus University (Denmark)

Lorenzo Pavesi, Università degli Studi di Trento (Italy)

Stefano Pelli, Istituto di Fisica Applicata "Nello Carrara" (Italy)

Andrew W. Poon, Hong Kong University of Science and Technology

(Hong Kong, China)

Joyce K. Poon, University of Toronto (Canada)

Miloš A. Popović, Boston University (United States)

Stefan F. Preble, Rochester Institute of Technology (United States)

Jeremy Witzens, Rheinisch-Westfälische Technische Hochschule Aachen (Germany)

Dan-Xia Xu, National Research Council Canada (Canada)

Koji Yamada, National Institute of Advanced Industrial Science and Technology (Japan)

Zhiping Zhou, Peking University (China)

Session Chairs

1 Optical Transcievers and Manufacturing

Roel G. Baets, Photonics Research Group (Belgium)

2 Emerging Concepts and Technologies I

Peter O'Brien, Tyndall National Institute (Ireland) 
3 Emerging Concepts and Technologies II

Peter O'Brien, Tyndall National Institute (Ireland)

$4 \quad$ Lasers and Amplifiers

Roel G. Baets, Photonics Research Group (Belgium)

$5 \quad$ III-V on Si Photonic Devices and Circuits

Laurent Vivien, Centre de Nanosciences et de Nanotechnologies (France)

$6 \quad$ Mid-IR Photonics

Vincent Reboud, CEA-LETI (France)

$7 \quad$ Mode Diversity and Light Coupling

Peter O'Brien, Tyndall National Institute (Ireland)

8 Wavelength Diversity Devices and Systems

Andrea I. Melloni, Politecnico di Milano (Italy)

9 Quantum Photonics

Laurent Vivien, Centre de Nanosciences et de Nanotechnologies (France)

10 Reconfigurable and Tunable Photonic Devices

Dimitris Fitsios, C2N - CNRS (France) 